\title{
Infiéis em casa. Jesuítas e escravos muçulmanos (Nápoles e Espanha, século XVII)
}

EMANUELE COLOMBO ${ }^{I}$

$\mathrm{E}$ STE ARTIGo situa-se na confluência de três diferentes correntes de pesquisa que vêm crescendo nos últimos anos. A primeira mostra a relevância do fenômeno da escravatura na Europa mediterrânica até o século XVIII. ${ }^{1} \mathrm{~A}$ segunda destaca o número surpreendentemente elevado de muçulmanos, não apenas escravos, que estavam presentes na Europa no início do período moderno; eles muitas vezes foram negligenciados pelos historiadores por causa de seu status particular como uma minoria "invisível" ou como "estranhos familiares" (Dackhlia; Vincent, 2011; Dackhlia; Kaiser, 2013; Valensi, 2012). A terceira considera o impacto cultural e social da conversão tanto na Europa como no ultramar (Krstić, 2011; Dursteler, 2011; 2013; 2014). No caso específico do Islã, complementando o conhecimento sobre os cristãos convertidos ao Islã, ou os "cristãos de Allah", há também um número crescente de pesquisas sobre os "muçulmanos de Cristo", ou seja, muçulmanos que se converteram ao cristianismo. ${ }^{2}$ Contribuindo para essa literatura vasta e complexa, este artigo explora o apostolado jesuíta junto aos escravos muçulmanos em Nápoles e em diferentes cidades da Espanha no século XVII. As fontes deste ensaio são principalmente tratados, manuais, relatórios e cartas, tanto publicadas quanto não publicadas. Esses documentos levantaram a questão da confiabilidade e da demanda de uma análise cuidadosa e crítica, uma vez que os limites entre os gêneros da história, a propaganda interna e espiritual e a edificação são, muitas vezes, tênues. No entanto, um ponto de vista jesuíta, encoberto pela retórica missionária e indisponível de outra forma, é encontrado nessas fontes, as quais destacam métodos e estratégias dos missionários jesuítas e esclarecem o status especial que o apostolado possuía em relação aos escravos muçulmanos, algo que se manteve na mente dos jesuítas. Enquanto a Europa foi o cenário de missões a fim de converter os escravos muçulmanos, e essas missões foram consideradas uma variação das chamadas "missões populares", elas eram frequentemente carregadas de um valor simbólico mais profundo. Isso se dava pois os interlocutores dos missionários eram "infiéis" tão diferentes em sua cultura e em seus hábitos que os jesuítas usavam formas de conversão muito semelhantes àquelas que empregavam nas missões no ultramar. Em suma, encontramos aqui um modelo híbrido de missão, dirigido a “outras Índias” e localizado a meio caminho entre as missões no estrangeiro e as missões populares na Europa. 
Este artigo começa com uma breve visão geral que contextualiza o apostolado jesuíta junto aos escravos muçulmanos. Em seguida, é feita uma análise do status social dos escravos convertidos, ambos considerando tanto o ponto de vista da Igreja Católica do início da era moderna, quanto o ponto de vista específico das estratégias missionárias dos jesuítas.

\section{Jesuítas e escravos muçulmanos em Nápoles e Espanha}

Durante o século XVII, Nápoles foi um dos portos italianos mais importantes e um pivô para o comércio de escravos. Embora seja sempre difícil estimar números precisos, muitos estudos determinaram que, no início do século XVII, houve em Nápoles uma presença estável de pelo menos dez mil escravos muçulmanos, principalmente capturados na guerra e na pirataria que vieram do Magreb (Boccadamo, 2010). Alguns deles eram propriedade do Reino de Nápoles e trabalhavam nas galés. Outros, principalmente mulheres e crianças, eram de propriedade de famílias e trabalhavam como empregados domésticos. Os escravos não eram os únicos muçulmanos na cidade: Nápoles hospedou uma comunidade muçulmana grande e bem organizada que gozava de uma boa quantidade de autonomia e estava sempre pronta para defender seus direitos e reivindicações. $\mathrm{Na}$ cidade, os muçulmanos eram frequentemente empregados como agiotas; eles estabeleceram uma mesquita no Fondaco dei Mori, perto do porto, onde as autoridades religiosas muçulmanas lideravam os serviços de oração que eram geralmente frequentados por cristãos curiosos (Boccadamo, 2010, p.13-15). ${ }^{3}$

A partir de meados do século XVI, sacerdotes diocesanos e várias ordens religiosas fortaleceram o apostolado junto a escravos muçulmanos em uma campanha que teve a colaboração de autoridades eclesiásticas e políticas. Nápoles logo se tornou a cidade italiana com o maior número de escravos muçulmanos convertidos ao cristianismo. ${ }^{4}$ Como Peter Mazur $(2009$, p.28) observou recentemente, "para os governantes de Nápoles, tanto clérigos quanto leigos, a conversão e assimilação na sociedade de um escravo muçulmano era uma vitória cheia de simbolismo que incorporava os mais altos valores do Igreja Católica e da monarquia espanhola". Os jesuítas, que estavam presentes na cidade desde 1552 , não ficaram indiferentes a esse apostolado e, no final da década de 1580 , começaram a converter escravos que pertenciam às famílias napolitanas e escravos nas galés. ${ }^{5}$

Foi, no entanto, no século XVII que a Companhia de Jesus lançou um apostolado mais sério para os escravos muçulmanos em Nápoles. Em 1601, os jesuítas Girolamo d'Alessandro e Giacomo Antonio Giannoni, depois de se encontrarem com escravos muçulmanos enquanto estavam pregando na cidade, criaram uma confraria leiga, a Congregação da Epifania, para "tirá-los do inferno" ${ }^{6}$ Em princípio, os membros da confraria visitavam os escravos nos lares de seus senhores; depois eles passaram a reuni-los na igreja do colégio jesuíta, a fim de catequizá-los. O sucesso da congregação e desse apostolado jesuíta variou ao longo do século, dependendo do apoio dos bispos locais, da nobreza e da 
presença de missionários particularmente zelosos. Esse foi o caso de Baldassarre Loyola († 1667), um antigo príncipe muçulmano de Fez, Marrocos, que converteu-se, juntou-se à Companhia de Jesus, e foi enviado para Gênova e Nápoles para pregar aos escravos em preparação para a missão no império Mogol, na Índia (Colombo, 2013).

Durante sua estada de um ano em Nápoles (1666-1667), Loyola converteu mais de trezentos muçulmanos, o que foi possibilitado pelo seu conhecimento do árabe e do Alcorão e pelo respeito que lhe foi concedido pelas autoridades civis e eclesiásticas. No final do século, o apostolado jesuíta junto aos escravos muçulmanos era ainda ativo: conhecemos a história de Francesco di Geronimo ( $\uparrow 1716)$, um proeminente pregador de missões populares que trabalhou incansavelmente para converter os escravos muçulmanos nas galés (Bonis, 1747, p.29-30). ${ }^{7}$

No século XVII, os muçulmanos ainda eram uma população significativa na Península Ibérica, mesmo após a expulsão final dos mouriscos (1609-1614). Ainda havia comunidades de descendentes dos mouriscos que escaparam das expulsões, preservando secretamente seus costumes e tradições islâmicas, além dos escravos muçulmanos que foram capturados no norte da África ou tiveram que emigrar voluntariamente do Magreb devido à fome frequente (Vincent, 2001, p.195). A maior parte do conhecimento sobre os mouriscos produzidos ao longo das últimas décadas de alguma forma escondeu um paradoxo intrigante: a mesma monarquia que expulsou muçulmanos convertidos, cujos ancestrais viveram na Espanha durante séculos, ao mesmo tempo deu as boas vindas a outros muçulmanos vindos de fora, com a esperança de convertê-los (Vincent, s. d., v.l, p.615). ${ }^{8}$ Os documentos jesuítas fornecem evidências desse fenômeno: durante os anos 1609 e 1610, enquanto a expulsão final dos mouriscos estava ocorrendo, mais de duzentos escravos muçulmanos receberam o batismo no Colégio jesuítico imperial em Madri. ${ }^{9}$ As missões continuaram ao longo do século: a partir de 1620, Francisco de Alemán († 1644) pregou aos muçulmanos em Granada, a pedido do arcebispo local. ${ }^{10}$ Juan de Almarza († 1669) estava ativo em Múrcia, onde havia uma grande comunidade de muçulmanos; ele também deixou um fascinante catecismo de moros, um catecismo manuscrito para ajudar a conversão dos muçulmanos. ${ }^{11}$ Em Barcelona, Francisco Poch pregou aos escravos muçulmanos nas galés durante pelo menos nove anos (1676-1685) e descreveu seu ministério em correspondência com Roma. ${ }^{12}$ Finalmente, os dois mais famosos "apóstolos" dos escravos muçulmanos são certamente Juan Gabriel Guillén († 1675) e Tirso González de Santalla († 1705) (Reyero, 1913).. ${ }^{13}$ Em muitas cidades do sul da Espanha, mas também em Madri, eles pregavam tanto nas missões populares tradicionais para católicos quanto nas missões especiais para os escravos muçulmanos. González, que mais tarde se tornou o décimo terceiro superior geral da Sociedade, compôs um Manual para a conversão dos muçulmanos, que teve ampla difusão, desde a Europa até a China, sendo traduzido em 
polonês e árabe, e se tornou o livro de referência da Companhia sobre o assunto (Santalla, 1687). ${ }^{14}$

Quando se converteram e foram batizados, seja sob pressão dos missionários, seja por um desejo sincero, os escravos muçulmanos levantaram uma questão importante dentro da Igreja Católica. Muitos católicos questionaram: como poderia um cristão ser escravo de outro cristão?

\section{Escravos cristãos, mestres cristãos}

"Se você disser que é cristão, não será um escravo" (apud Boccadamo, 2010, p.16). Esse ditado, popular na comunidade muçulmana no início da Nápoles moderna, é definitivamente um reflexo enganoso da realidade histórica. $\mathrm{Na}$ verdade, como muitos estudiosos mostraram recentemente, os escravos muçulmanos que se converteram ao catolicismo não obtiveram a liberdade (Bono, 1999). A alforria de escravos era regulada pelas autoridades civis e, nos reinos espanhóis, nunca foi concedida como uma consequência da conversão. Mesmo assim, para a Igreja Católica, o status de escravos muçulmanos convertidos criou um dilema moral. Como poderia um cristão manter outro cristão como escravo? Desde a Idade Média, teólogos e canonistas discutiram essa questão, fornecendo respostas diferentes (Kedan, 1985, p.321-32). No começo do período moderno, a visão mais comum era de que era proibido escravizar um cristão - por exemplo, quando descobrissem que um prisioneiro de guerra era um indivíduo batizado. ${ }^{15}$

No entanto, se um muçulmano escravo decidisse se converter, seu status servil não mudaria. A missão de converter escravos foi considerada pelos teólogos um gesto de caridade, não um dever. A manutenção do status servil dos escravos convertidos também foi inquestionável, apesar do decreto (motu proprio) emitido pelo papa Paulo III em 1549 e confirmado por Pio V em 1566, que "ditava que qualquer escravo que tinha sido batizado poderia vir para o Monte Capitolino, sede da administração municipal da cidade de Roma, e ser-lhe concedida a liberdade e o status de cidadão romano" (Mazur, 2009, p.30). O fato de que o decreto papal acabou não sendo aplicado na prática revela tanto uma discrepância entre a lei e a realidade nesse assunto quanto um medo difundido no mundo católico de que os muçulmanos convertidos voltassem para os seus países e sua religião. ${ }^{16} \mathrm{O}$ mesmo cenário aparece em documentos jesuítas do início da era moderna em Nápoles e na Espanha. Por exemplo, quando jesuítas napolitanos herdavam um escravo de um benfeitor, eles corriam para libertá-lo, não por obrigação, mas sim para "evitar murmúrios" e mostrar que não estavam sendo gananciosos. ${ }^{17} \mathrm{Na}$ Espanha, após o batismo de um escravo, o patrão às vezes lhe dava dinheiro para sua libertação; no entanto, esta era claramente uma escolha opcional, não uma obrigação, além de não acontecer com frequência. ${ }^{18}$

Fiéis a essa tradição, os jesuítas nunca pressionaram os senhores a libertarem de escravos convertidos, mas estavam frequentemente preocupados com o tratamento de seus escravos e tentavam melhorar suas condições de vida. ${ }^{19}$ Eles 
também estavam bem cientes de um acordo tácito de reciprocidade em relação ao tratamento de escravos muçulmanos na Europa e de escravos cristãos no norte da África: os jesuítas, que estavam frequentemente envolvidos na libertação de cristãos cativos de muçulmanos, temiam as repercussões contra os cristãos em resposta a abusos contra escravos muçulmanos.

Nessa intersecção complexa de questões teológicas e morais permeada por circunstâncias políticas, uma coisa ficou clara na mente dos jesuítas: converter muçulmanos escravos era uma forma de apostolado extremamente atraente, e também era útil para outros católicos que poderiam ajudar nessa empreitada.

\section{Convertendo em casa}

A última década do século XVI foi marcada na Companhia de Jesus por uma forte ênfase nas missões sob pressão do general superior Claudio Acquaviva (1581-1615), que insistentemente lembrou que uma vocação jesuíta exigia que eles não fossem "reunidos e vinculados a um lugar particular", mas, ao contrário, "que fossem onde houvesse maior necessidade e exigência das almas". ${ }^{20}$ Acquaviva apontou que a Europa, e não apenas as Índias, deveria ser vista como um imenso campo de missão. A consequência foi o crescimento das missões jesuítas populares nas cidades e campos da Europa, seguindo estilos e estratégias específicos dos jesuítas. ${ }^{21}$ Em Nápoles e na Espanha, as missões destinadas aos escravos muçulmanos surgiram "quase por acaso" quando os jesuítas tomaram consciência de sua presença nas casas da nobreza. Os muçulmanos eram uma parte integrante do tecido social nas cidades onde viviam e tinham significativas interações com os católicos. Portanto, não é surpreendente que o estilo daquelas missões se assemelhasse à abordagem teatral das missões jesuíticas populares (Fumaroli, 1990; Majorana, 2002).

Em Nápoles, os sermões de Baldassarre Loyola às vezes duravam mais de quatro horas, e ele pregava em público tanto para muçulmanos como para cristãos, e em particular para "os muçulmanos mais teimosos". ${ }^{22} \mathrm{O}$ púlpito era transformado em um palco, onde cada detalhe era estudado para impressionar os interlocutores. Na Espanha, um jesuíta a fim de persuadir seu público muçulmano, realizava monólogos dramáticos:

Virando as costas para o público e de frente para a parede, ele limpou o suor de sua testa com a mão e, em seguida, colocou a palma da mão na parede e exclamou em voz alta: "Oh parede, ouça a Palavra de Deus, e seja testemunha do fato de que tenho pregado a verdade a essas pessoas insensíveis". E então, voltando-se para os muçulmanos, ele falou para eles ameaçadoramente: "Eu serei rigoroso contra vocês diante de Deus no Dia do Julgamento. Eu vou condenar sua teimosia perante o juiz supremo [...]. Ó bom Deus! Derreta a dureza de seus corações!"³

Procissões e grandes cerimônias, que foram usadas nas missões populares jesuítas, eram ainda mais importantes no contexto muçulmano, uma vez que eram instrumentos para encurtar a distância cultural. Escrevendo de Barcelona 
em 1680, Francisco Poch relatou que "durante a Semana Santa as galés foram decoradas como uma igreja". Cada navio tinha três altares e os bancos eram adornados com flores. Entre as imagens, uma da Virgem Maria - uma figura altamente respeitada no mundo muçulmano - foi considerada um terreno comum possível de ser explorado junto aos escravos muçulmanos. ${ }^{24}$

Quando pregavam para escravos, os missionários enfrentavam diferentes problemas, sendo o mais grave a falta de cooperação dos mestres: eles estavam relutantes em enviar os escravos aos serviços religiosos, temendo que pudessem perder o que consideravam ser sua propriedade privada ou serem obrigados a tratar seus escravos de forma mais humana. Os jesuítas frequentemente pediam a colaboração da nobreza local, que através da pressão social poderia persuadir os senhores a cooperarem. Em Nápoles, aproveitando seu status de ex-príncipe, Loyola entrou em contato com o vice-rei Pedro Antonio de Aragón e sua esposa; eles enviaram seus próprios escravos para ouvir as homilias de Loyola e encorajaram os nobres da cidade a fazer o mesmo. ${ }^{25}$ Em Sevilha, durante uma campanha extremamente bem-sucedida em 1672, González e Guillén receberam ajuda do conhecido nobre Don Miguel de Mañara, cavaleiro de Calatrava e hermano mayor, ou líder de uma confraria local para leigos, a Santa Hermandad de la Caridad. Don Miguel fez todos os esforços para reunir os escravos muçulmanos, inclusive pagando a cada um deles o equivalente a um dia de salário para cada dia que participassem da missão. ${ }^{26}$ As confrarias para leigos também eram cruciais em Nápoles: era mais fácil para as pessoas leigas se conectarem com os escravos muçulmanos, que também estavam com medo e relutantes em ter contato direto com os padres ou autoridades civis. Além disso, a participação dos católicos leigos nessas missões foi extremamente útil no fortalecimento de sua própria fé: os jesuítas frequentemente tinham mais confiança quanto ao benefício de suas missões para os católicos envolvidos nelas, do que quanto ao resultado dessas entre os muçulmanos. ${ }^{27}$

As missões jesuíticas na Europa eram frequentemente dedicadas ao cuidado pastoral de doentes e pessoas à beira da morte (Callado, 2006, p.251ss.). Isso também se aplica ao ministério entre os muçulmanos moribundos nas galés, nas casas dos seus proprietários e nos hospitais. Depois de uma corrida contra o tempo, a conversão de um escravo moribundo era celebrada como um triunfo especial. Os jesuítas muitas vezes se aproveitavam da fraqueza corporal dos escravos moribundos a fim de convertê-los, mas eles nunca reconheceram isso. Pelo contrário, consideravam que as conversões em leito de morte seriam as mais verdadeiras, pois os convertidos não buscavam benefícios sociais ou econômicos. González usou esse argumento para depreciar o fenômeno dos "renegados", cristãos que se converteram ao islamismo, que eram um verdadeiro espinho do lado da propaganda católica. Embora fosse verdade que muitos cristãos "levados em cativeiro pelo diabo" abraçaram o Islã pelas vantagens materiais, de acordo com González eles nunca foram convertidos em seu leito da morte. ${ }^{28}$ 
As fontes e relatórios das missões destacam a oscilação entre a "pedagogia do medo" e a "pedagogia da caridade", uma estratégia dupla que não era nova no estilo missionário da Companhia de Jesus. A fim de avisar a respeito das consequências da fidelidade teimosa dos muçulmanos ao Islã, os jesuítas falavam ameaçadoramente sobre o inferno no qual os escravos ficariam confinados se não se convertessem.

A descrição do inferno - um tópico recorrente na tradição popular das missões - foi adaptada para o público muçulmano e foi identificada como o reino de Maomé. ${ }^{29}$ Em 1610, em Nápoles, um escravo muçulmano que estava morrendo não quis se converter. Um jesuíta visitou-o e, pegando uma vela, aproximou-a da mão do escravo, que afastou a mão para não ser queimado. $\mathrm{O}$ jesuíta disse: "Oh amaldiçoado, você foge desse pequeno fogo que é como a água, se comparado ao fogo do inferno? O que você vai fazer quando, em poucas horas, você for para a casa dos demônios, onde não só a sua mão, mas todo o seu corpo e alma irão queimar para a eternidade?". ${ }^{30}$ Durante suas homilias em cidades espanholas, González costumava exibir a imagem amedrontadora de uma alma condenada ao fogo do inferno, para mostrar aos muçulmanos o seu destino se eles não se convertessem. ${ }^{31}$ Ao mesmo tempo, a caridade foi fundamental para mover as almas dos muçulmanos. González e Guillén relatam que em Sevilha vários muçulmanos foram convertidos porque foram acolhidos pelo arcebispo, o qual cuidou e consolou os doentes no hospital local. Em Nápoles, muitas conversões ocorreram no Hospital de Incuráveis, onde Jesuítas e outros religiosos ajudaram os doentes e os moribundos. ${ }^{32}$

As missões junto aos escravos muçulmanos, tanto em Nápoles como na Espanha, foram consideradas extensões das missões populares, direcionadas tanto à conversão dos muçulmanos quanto ao progresso na fé dos católicos batizados. Quando os senhores traziam seus escravos à igreja, os jesuítas pregavam aos primeiros, destacando a graça e as responsabilidades de seu status de cristãos. Além disso, as cerimônias imponentes organizadas para os muçulmanos atraíram muitos interessados pelo cristianismo e tiveram impacto em toda a cidade. ${ }^{33}$ Os muçulmanos eram uma parte significativa da sociedade nas cidades em que viviam. Ao mesmo tempo, eles representavam algo mais aos olhos dos jesuítas: como interlocutores, eram "infiéis".

\section{Convertendo "infiéis"}

As fontes dos jesuítas revelam a mesma atitude ambígua que frequentemente encontramos em outras aproximações europeias ao Islã no século XVII: hostilidade e fascínio, repulsão e atração. De uma perspectiva teórica, o Islã era um perigo para a cristandade. Isso foi claramente percebido pelos jesuítas em Nápoles e na Espanha, onde estiveram envolvidos na propaganda antiotomana durante o "longo século XVII", da Batalha de Lepanto (1571) até a Batalha de Viena (1683). Em seus escritos, os jesuítas apoiavam uma "cultura de antagonismo" contra o Islã, e a conversão dos "mais perigosos inimigos da fé" foi 
considerada um triunfo espiritual para o catolicismo, que antecipou ou reforçou as vitórias militares (Poumarède, 2009; Tejada, 1959). Os argumentos medievais que foram reiterados no início das polêmicas modernas antimuçulmanas combinavam perfeitamente com essa abordagem (Ibarra, 1989). González em seu Manual, Almarza em seu Catecismo, e Baldassarre Loyola em suas homilias reforçaram amplamente os argumentos da polêmica medieval: a condenação de Maomé como um falso profeta, a negação da moralidade sexual islâmica, e a definição do Islã como "a soma de todas as heresias." O Islã foi retratado como irracional, incompatível com a natureza humana. Em uma seção do seu Manual, por exemplo, González demonstrou "a falsidade do Alcorão através do próprio Alcorão", e perguntou sarcasticamente, "Como não se pode ficar atordoado e surpreso que seres humanos razoáveis considerem esses contos e esses sonhos ridículos como um artigo de fé? Como podem reverenciar Maomé, que inventou todos esses contos?". ${ }^{34}$

Ao mesmo tempo que repetiam esses argumentos, os jesuítas logo perceberam que esses eram esforços insuficientes para converter muçulmanos. Em autênticos encontros com escravos muçulmanos, era necessário ouvir, bem como doutrinar, para se aproximar dos muçulmanos de maneira humanizada e estabelecer um vínculo com eles. Tais abordagens foram mais fáceis para jesuítas que já haviam passado algum tempo em terras muçulmanas, e mais fácil ainda para um ex-príncipe muçulmano como Loyola. Em outros casos, os jesuítas tentaram usar histórias de proeminentes muçulmanos convertidos, o que poderia atrair a atenção dos escravos. ${ }^{35}$ Para tornar os encontros mais eficazes, os jesuítas colocavam em prática diferentes formas de acomodação, como seus colegas fizeram em outras missões no ultramar.

"Acomodar-se aos outros", na interpretação que a Companhia de Jesus deu a essa noção, era um meio necessário para obter o fim de "vencer e entregá-los a Cristo" (Prosperi, 1995, p.173).

Uma forma intrigante de acomodação foi a abordagem em relação às mulheres muçulmanas, um destaque frequente nos relatos dos jesuítas, apesar do fato de as mulheres serem minoria entre os escravos. As mulheres eram geralmente apresentadas como razoáveis, sensíveis e dotadas de virtudes naturais. Em 1649, em Nápoles, os jesuítas presenciaram a conversão de Cata, "uma jovem de 25 anos, mulher, alta, nobre e amável, extremamente talentosa como muitas vezes são pessoas nobres; ela alegou ser a filha de um governante muçulmano". No começo, ela não queria se converter, porque tinha orgulho de sua religião; no entanto, quando ela ficou mortalmente doente, seu senhor pediu a um jesuíta que aproveitasse a situação. Possivelmente, ela foi persuadida por um sonho e decidiu se converter. Ela morreu olhando para a cruz, e "depois de sua morte, o mau cheiro e a deformidade da doença desapareceram e o corpo dela se tornou perfumado e belo". ${ }^{36}$ Em Málaga, uma jovem muçulmana que se converteu foi informada de que seria liberta e poderia retornar para Argel, sua cidade natal; 
"ela gentilmente respondeu que preferiria ficar na Espanha como escrava entre os cristãos, do que voltar para sua terra muçulmana como uma mulher livre". ${ }^{37}$ Mulheres convertidas eram particularmente eficazes na conversão de outras mulheres muçulmanas, e os jesuítas muitas vezes buscavam a ajuda delas. ${ }^{38} \mathrm{~A}$ representação extremamente positiva das mulheres - nada frequente nas missões populares tradicionais dos jesuítas - era provavelmente um argumento implícito para criar um contraste com o status inferior das mulheres no Islã, e esse foi um dos argumentos dos jesuítas para convencer o público da falsidade da religião muçulmana. ${ }^{39}$

O problema da linguagem, uma questão-chave nas missões jesuítas no ultramar, era também levantado nas missões junto aos escravos muçulmanos. Em Nápoles, os jesuítas logo perceberam que era necessário dominar o árabe para poderem se comunicar de forma eficaz com os escravos. A importância de estudar o árabe não era nova na Companhia de Jesus. Inácio tinha planejado vários projetos - a maioria dos quais nunca foram realizados - para criar faculdades de língua árabe, a fim de promover missões jesuíticas no norte da África. Mais tarde, o Colégio Romano introduziu o ensino de árabe, bem como uma prensa tipográfica com o tipo árabe. ${ }^{40}$ Embora essas tentativas anteriores visassem terras a serem evangelizadas fora da Europa, em Nápoles uma instituição especial foi criada para a evangelização dos escravos muçulmanos. Em 1603, os jesuítas Pietro Antonio Spinelli e Mariano Manieri fundaram a Academia de Línguas (Accademia dei Linguaggi) no Colégio Massimo em Nápoles (Santagata, 17561757 , v.1, p.572) ${ }^{41}$ Manieri tinha ido a Argel treze vezes em nome do vice-rei de Nápoles em missões para a redenção de cativos cristãos. "Quando ele voltou para Nápoles com o conhecimento de diferentes línguas africanas, ensinou-as para alguns dos nossos jovens [jesuítas] [...]. Desta forma, Manieri adquiriu alguns companheiros para catequizar muçulmanos em Nápoles" (Santagata, 1756-1757, v.2, p.469)..$^{42}$ A importância das línguas foi retomada alguns anos depois, na congregação provincial de Nápoles (1619), quando outro jesuíta foi recomendado como um possível professor de línguas árabes (Santagata, 17561757 , v.1 , p.42). Ele era Pietro Ferraguto († 1656), autor de uma das primeiras gramáticas turcas da Europa. ${ }^{43}$ Nascido em Messina, Ferraguto esteve preso durante cerca de seis anos na Tunísia. De volta a Nápoles, ele decidiu dedicar-se a evangelização dos escravos muçulmanos, "pela salvação daquelas almas imersas em erros", como escreveu ao cardeal Roberto Bellarmino na dedicatória de sua gramática (Bombaci, 1940, p.206-7). Apesar do fato de que a Academia de Línguas ter sido um experiência de curta duração que nunca floresceu, o mero fato de sua criação, junto com o engajamento de Maniero e Ferraguto nas atividades missionárias, mostra uma sensibilidade particular em um período em que o estudo acadêmico de idiomas orientais estava em seus estágios iniciais. Em Roma, alguns anos depois, a Congregação de Propaganda Fide lançou outros planos sistemáticos na mesma direção (Pizzorusso, 2009, p.253-88). 
$\mathrm{Na}$ Espanha, de acordo com relatórios missionários, a necessidade de aprender árabe parecia ser menos urgente: a maioria dos escravos podia entender, e às vezes até ler línguas ibéricas, havendo também poucas referências à necessidade de um intérprete. ${ }^{44}$ No entanto, houve jesuítas que estudaram árabe, conheciam os livros impressos na Europa nas línguas orientais e produziam traduções, gramáticas e dicionários. Eles se relacionavam com outros missionários: González, por exemplo, que não tinha um conhecimento direto da cultura muçulmana, esteve em contato com o famoso orientalista jesuíta Tomás de León (García-Arenal; Mediano, 2013, p.315-19; 1991, p.413-14).

Uma forma extrema de acomodação pode ser encontrada em dois diálogos fictícios, propostos como exemplos de uma abordagem prática para a aproximação dos muçulmanos. Na parte conclusiva de sua gramática turca, Pietro Ferraguto inseriu um "Diálogo entre um turco e um cristão". Na primeira parte do diálogo, o cristão se mostra escandalizado pelos hábitos muçulmanos, como a poligamia e a facilidade com que os homens podem abandonar suas esposas; no final, no entanto, ele parece convencido de que ele e os muçulmanos adoram ao mesmo Deus. O turco diz: "Vamos orar a Deus com todo o nosso coração para que ele nos ilumine e nos ajude a conhecer a verdade", e o cristão responde: "Espero que Deus permita que nos encontremos no céu, se seguirmos sua lei". ${ }^{45}$ Em seu Manual, González apresentou um longo diálogo com um cenário semelhante. O discurso final do cristão é intrigante: "Ore persistentemente a Deus para iluminar-te, para que possas ser digno da sua luz; evite vícios, pratique a piedade, ame a Deus acima de todas as coisas e ao próximo como a si mesmo". ${ }^{46}$ Ao contrário do modelo convencional de diálogos semelhantes, aqui os dois muçulmanos não se convertem, sugerindo que González e Ferraguto foram provavelmente inspirados por encontros reais. A ênfase nos aspectos comuns entre cristãos e muçulmanos é radicalmente diferente da abordagem polêmica usada pelos jesuítas em suas descrições teóricas do Islã.

Enquanto o clímax das tradicionais missões populares junto aos católicos era geralmente a confissão sacramental, que marcava o retorno a uma vida cristã, os batismos eram o clímax das missões junto aos escravos muçulmanos. Os jesuítas sempre explicavam a importância dessas cerimônias religiosas, transformadas em grandes eventos barrocos. "Tanto os fiéis como os infiéis, participavam daquelas cerimônias sagradas", comentou González, "e olhando suas solenidades, entendiam que havia algo grande em jogo [...]; isso não aconteceria se eles apenas vissem homens entrando na água benta". ${ }^{47}$ Em Nápoles e na Espanha, às vezes, os jesuítas chamavam o arcebispo para celebrar batismos e confirmações de escravos, tendo nobres e autoridades civis que competiam para serem seus padrinhos. ${ }^{48}$ Para os jesuítas, era particularmente importante celebrar esses batismos em suas próprias igrejas: tanto em Nápoles como na Espanha, muitas vezes romperam com a tradição de celebrar tais batismos na catedral, provocando reclamações e ciúmes de outras ordens religiosas (Reyero, 1913, p.69). ${ }^{49}$ 
A inferioridade social dos escravos levanta a questão do nível de pressão que os jesuítas e os patrões podem ter exercido para que eles se convertessem. Claro, sempre existiram formas de pressão. No entanto, os documentos revelam nas entrelinhas uma imagem mais colorida e cheia de nuances do que poderíamos imaginar. Existiam muçulmanos que recusavam a se converter e atacavam abertamente os jesuítas; os alfaquis, ou especialistas em lei islâmica, frequentemente trabalhavam contra os jesuítas e persuadiam os escravos a não se converterem. Os muçulmanos não eram passivos perante o apostolado jesuíta.

Além disso, as fontes jesuítas insistem sempre na importância da liberdade dos escravos: uma conversão só era válida se fosse livre. "Embora possamos forçá-los a participar de nossas missões", costumava dizer González aos escravos muçulmanos, "não queremos usar esse tipo de violência; nós apenas pedimos e imploramos que vocês participem". ${ }^{50}$ Esse não era apenas outro exemplo de retórica jesuítica.

Um estudo recente mostrou que, a partir da segunda metade do século XVI, o direito canônico e a literatura teológica apresentavam fortes argumentos contra batismos forçados, influenciados pelo fracasso das conversões forçadas, o fiasco da estratégia católica em relação aos mouriscos e o debate sobre o batismo emergente do Novo Mundo (Poutrin, 2012). Os jesuítas não eram ingênuos a respeito da gama de motivos pelos quais os indivíduos eram batizados e muitas vezes questionavam a sinceridade das conversões. Eles reconheciam que os escravos muçulmanos poderiam se converter na esperança de receberem um melhor tratamento. Esse foi o caso, por exemplo, dos muçulmanos sentenciados à morte em Nápoles, que esperando adiar suas execuções o quanto pudessem, simulavam um conflito espiritual (Mazur, 2009, p.37-8). O batismo muitas vezes não quebrava o vínculo dos convertidos com seus correligionários ou suas pátrias, e às vezes os escravos secretamente permaneciam muçulmanos. Conscientes dessas possibilidades, os jesuítas se preocupavam em fornecer uma sólida educação religiosa aos convertidos e se preocupavam com os episódios frequentes de muçulmanos convertidos que "retornavam" à sua seita por falta de educação religiosa. Por essa razão, os jesuítas em Nápoles fundaram um oratório especificamente para os escravos batizados e a Casa dos Catecúmenos que funcionou durante alguns anos (1637-1649) seguindo o modelo de instituições similares que existiam em outras cidades italianas. ${ }^{51} \mathrm{Na}$ Espanha, González e Guillén organizaram escolas de doutrina cristã para escravos e, muitas vezes adiavam batismos a fim de garantir uma educação mais eficaz dos catecúmenos. ${ }^{52}$

Em suas narrativas, os jesuítas citavam as cartas vindas das Índias referentes aos seus desejos de martírio - um tema tradicional das missões no ultramar - e enfatizaram as reações hostis dos muçulmanos à sua pregação (Roscioni, 2000). Guillén relatou que, durante uma missão em Málaga, os muçulmanos cobriram a cabeça com as mãos e as mulheres usaram seus véus, temendo que os missionários estivessem colocando um feitiço maligno sobre eles com seus gestos. 
Alguns deles gritaram contra os jesuítas, ameaçando que iriam "escrever para a África, sugerindo que [os muçulmanos] fritassem os cativos [cristãos] em óleo, uma vez que eles eram inimigos de Maomé". ${ }^{53}$ Loyola escrevia que em Nápoles os muçulmanos "estavam revoltados e confusos, e fecharam os ouvidos, não ouvindo meus argumentos contra Maomé", e lembrou que uma vez, durante uma homilia, "um sacerdote maometano, $[\ldots]$ ouvindo o que eu estava dizendo sobre Maomé, foi para o meio da assembleia e começou a gritar como um amaldiçoado". ${ }^{54}$

Loyola frequentemente se arriscava a ser morto por muçulmanos; os missionários se encontravam particularmente em risco quando pregavam nas galés, onde a coesão social dos muçulmanos era mais forte. As missões com escravos muçulmanos levantaram questões semelhantes às das missões no ultramar: a necessidade de acomodação, os debates a respeito do batismo forçado e o desejo de martírio. Mesmo estando na Europa, os jesuítas descreveram suas atividades pastorais como se estivessem nas Índias.

\section{Conclusão: outras Índias}

Os jesuítas em Nápoles e na Espanha usaram estratégias missionárias similares no apostolado com os escravos muçulmanos, e suas cartas e relatórios circularam em ambas as direções. A história de Baldassarre Loyola oferece um exemplo claro da eficiência dessa rede jesuíta. Em 1666, ele pregou aos escravos muçulmanos em Nápoles com grande sucesso; quatro anos depois, Guillén relatou a história de Loyola durante seus sermões para escravos muçulmanos em Marbella e atribuiu a conversão de cinco deles à intercessão do falecido jesuíta. ${ }^{55}$ A mesma história foi inserida no Manual de González, que foi publicado pela primeira vez em Madri, em 1687, e alguns anos depois foi publicado novamente em Nápoles, em benefício dos missionários locais (González, 1702).

A conviç̧ão de que a Espanha e o Reino de Nápoles eram dois lugares privilegiados para a conversão de escravos muçulmanos também era bem estabelecida entre os superiores jesuítas. Em 1598, Juan Bautista Pacheco, um jesuíta envolvido no apostolado dos mouriscos e muçulmanos na Espanha, queria criar um novo ramo da Companhia de Jesus, os Jesuítas Descalços, que seria especialmente dedicado ao apostolado para mouriscos e muçulmanos. ${ }^{56}$ Pacheco propôs seu plano ao general Acquaviva em Roma e secretamente visitou o papa Clemente VIII em Ferrara, o que irritou seus superiores. Antes de mandá-lo de volta para a Espanha, Acquaviva ordenou que ele passasse algum tempo no Reino de Nápoles, onde ele poderia ver por si mesmo que a Companhia não precisava mudar suas regras a fim de buscar um apostolado bem-sucedido entre os muçulmanos (Santagata, 1756-1757, v.1, p.48-9). ${ }^{57}$ Tal apostolado já existia.

Em Nápoles e na Espanha, os escravos muçulmanos tinham um status especial. Por um lado, faziam parte do tecido social das cidades nas quais viviam: por essa razão, missões jesuíticas junto aos escravos muçulmanos eram uma extensão de missões populares e também poderiam beneficiar católicos de diferen- 
tes classes sociais. Por outro lado, os escravos muçulmanos eram extremamente distantes da Igreja Católica. Essa distância foi evidenciada tanto em polêmicas contra o Islã, que retomou os clássicos argumentos medievais anti-islâmicos, e expressavam a necessidade de uma acomodação missionária à distinta cultura dos muçulmanos. Nos encontros reais, o tratamento especial recebido pelas mulheres muçulmanas, o desejo de aprender árabe e a tentativa de encontrar um terreno comum com os muçulmanos espelhava as estratégias dos jesuítas nas missões no ultramar. Essas atitudes não produziram resultados particularmente bem-sucedidos, mas confirmam "uma mudança inegável na abordagem missionária junto aos muçulmanos e ao Islã referente ao que traziam os textos produzidos pelos missionários católicos nas décadas anteriores. $\mathrm{O}$ que era realmente novo era a crença dos missionários de que eles compartilhavam hábitos em comum com os muçulmanos, definidos pelo uso da razão e pelo monoteísmo" (Heyberger, 2012, p.514). Embora a ênfase no monoteísmo seja fundamental nos dois diálogos fictícios analisados neste artigo, ambos escritos por jesuítas envolvidos em encontros concretos com os escravos muçulmanos, a atenção ao uso da razão também foi evidente na administração de batismos por parte dos jesuítas. No esforço dos jesuítas, podemos observar uma sensibilidade crescente em relação à libertação dos escravos e à instrução religiosa dos catecúmenos. Nessa evolução, os jesuítas se inspiraram em sua própria história e em sua experiência nas Índias.

No século XVII, os jesuítas viam as missões no ultramar como uma oportunidade fascinante e as missões populares na Europa - chamadas por eles de "nossas Índias" - como "um consolo para aqueles aos quais foram designadas tarefas inferiores ao apostolado ideal em terras distantes" (Prosperi, 1995, p.179). As missões junto aos escravos muçulmanos representavam uma terceira categoria entre a Europa e as Índias. Em 1603, o general Acquaviva visitou a província jesuíta de Nápoles; depois de selecionar um grupo de jesuítas que se candidataram às missões extraeuropeias, dirigiu-se àqueles cuja partida havia sido adiada. Como preparação para sua futura missão entre os “infiéis", ele disse que eles deveriam trabalhar na conversão dos escravos muçulmanos em Nápoles, e uma vez que estava claro que os escravos nem sempre seriam capazes de entender o italiano, os jesuítas tinham como tarefa estudar o árabe (Santagata, 1756-1757, v.1, p.94-5). Mais tarde, Baldassare Loyola, que esperava passar a vida no "grande campo" do Grand Mughal, foi requisitado pelo general para que "cultivasse o pequeno jardim" do apostolado com os escravos muçulmanos em Nápoles. ${ }^{58}$ Quando Francesco di Geronimo pediu para ser enviado ao Japão, ele recebeu a resposta de que "ele era digno de ser o apóstolo nas Índias desta cidade e no Reino de Nápoles", onde, de fato, ele se dedicou à conversão de escravos muçulmanos e tornou-se conhecido como o "apóstolo das galés". 59

O mesmo aconteceu na Espanha: Tirso González e Juan Gabriel Guillén, que repetidamente pediram para ir em missões no ultramar, encontraram sua vo- 
cação nas missões junto aos muçulmanos na Espanha (Colombo, 2012b, p.97137). Francisco Poch, que insistiu para ser enviado para Argel, mas foi obrigado a permanecer em Barcelona, escreveu para o general que nas galés "os debates são tão incansáveis e o fruto é tão abundante que todos acham que Deus nosso Senhor moveu as Índias para esta cidade. [...] Parece, para mim, que o nosso Deus quer que eu cultive com os infiéis locais o meu desejo de ir para Argel." ${ }_{60}$ A conversão de escravos muçulmanos em Nápoles ou na Espanha era concebida pelos jesuítas como uma maneira alternativa e eficaz de ir em missão "mesmo entre Turcos", como afirmou a Fórmula do Instituto, apesar de nunca deixarem os reinos europeus para as terras otomanas. Situadas entre as missões no ultramar, onde os jesuítas convertiam os "infiéis" em terras distantes, e as missões na Europa, onde eles tentavam salvar as almas de pessoas batizadas que não tinham educação religiosa, estavam em "outras Índias". Lá, os jesuítas podiam encontrar, converter, e batizar os "infiéis" em casa. ${ }^{61}$

\section{Notas}

1 Uma excelente visão historiográfica em Salvatore Bono (2002). Para a Itália e Nápoles, ver Bono (1999); para a Espanha, ver Alessandro Stella (2000).

2 Sobre os "renegados", ver Bennassar e Bennassar (1989). Sobre os muçulmanos que se converteram ao cristianismo, ver Acero (2006); Poutrin (2012).

3 Mesquitas e cemitérios para os muçulmanos existiam na mesma período em muitas cidades da Itália. Ver Bono (1999, p.241-52).

4 "Between 1583 and 1664, 2,365 slaves were baptized in Naples, more than twice the number registered over similar periods in Rome and Venice" (Mazur, 2013, p.21534, 224). Uma instituição-chave era a Congregação dos Catecúmenos, uma confraria de leigos que trabalhavam para a conversão de escravos muçulmanos criada pelo arcebispo de Nápoles, o cardeal Paolo Burali d'Arezzo († 1578). A Congregação começou a manter registros das administrações de baptismos (ver Nardi, 2005).

5 Tal foi o caso, por exemplo, de Giovan Francesco Araldo (†1599). Schinosi (17061711, v.1, p.431-2). Ver Francesco Divenuto (1998).

6 A congregação era informalmente conhecida como "Congregação dos Escravos". Ver Nardi (1967); Santagata (1756-1757, v.1, p.28-30).

7 Di Geronimo foi canonizado em 1839 pelo papa Gregório XVI.

8 Sobre os jesuítas e os mouriscos, ver Medina (1988, p.3-136).

9 Archivum Romanum Societatis Ies, Tolet. 37a, 460-466v.

10 O’Neill e Domínguez, 2001, 1:45; o arcebispo de Granada foi o cardeal Augustín de Spinola.

11 O’Neill e Domínguez, 2001, 1:79-80; Juan de Almarza, Catecismo de moros, Real Academia de la Historia, Madrid, Ms. 9/2263.

12 O’Neill e Domínguez, 2001, 4:3161-3162.

13 Em Guillén, ver O’Neill e Domínguez, 2001, 3:1841.

14 No livro e sua circulação, ver Colombo (2012a). 
15 Ver, por exemplo, o motu proprio Licet omnibus (1571), emitido por Pio V após a Batalha de Lepanto.

16 Mesmo quando foram resgatados regularmente, os muçulmanos batizados em Nápoles não podiam abandonar a cidade sem permissão especial. Ver Boccadamo (2010, p.32-5). Na segunda metade do século XVII, um proeminente canonista, o cardeal Giovanni Battista de Luca (1673, v.4, p.18-19), reforçou que um escravo que se converteu permanece escravo.

17 Archivum Romanum Societatis Ies, Ital. 62, 139v; 299; 317. Ital. 63, 144v; 148v. Ver também Boccadamo (2010, p.11-12).

18 Ver, por exemplo, González, Manuductio, 2:295.

19 Os jesuítas espalham histórias de senhores maldosos mortos por seus escravos, explicitamente apoiando os escravos. Ver Schinosi (1706-1711, v.1, p.433-4).

20 De jubilaeo et missionisbus (1590), citado em Paolo Broggio (2004, p.51).

21 Em missões populares na Espanha, ver Callado (2006); em Nápoles, ver Gentilcore (1994); Selwyn (2004).

22 Domenico Brunacci, Vita del Ammirabile P. Baldassarre Loiola de Mandes della Compagnia di Gesì, Archivum Romanum Societatis Ies, Vitae 103-4.

23 González, Manuductio, 2:299-300.

24 Francisco Poch para Gianpaolo Oliva, 10 de novembro de 1680, Archivum Romanum Societatis Ies, Arag. 27 II, 95. Sobre Maria como uma possível ponte entre cristãos e muçulmanos no medievo e no início da época moderna, ver Daniel (1960). Sobre o uso de imagens em um período anterior, ver Pereda (2008).

25 Baldassarre Loyola, Archivio Pontificia Università Gregoriana, 1060 I, 68.

26 González, Manuductio, 2: 291.

27 González, Manuductio, 2; Baldassarre Loyola, Archivio Pontificia Università Gregoriana 1060 I. A mesma ideia pode ser encontrada em diferentes livros jesuítas sobre a conversão de muçulmanos. Ver Colombo (2009, p.315-40).

28 González, Manuductio, 2:41. Baldassarre Loyola, Archivio Pontificia Università Gregoriana $1060 \mathrm{I}, 23 ; 61$.

29 Loyola a Brunacci, Nápoles, 2 de outubro de 1666, Archivio Pontificia Università Gregoriana, 1060 I, 10-11.

30 Archivum Romanum Societatis Ies, Neap. 72, 140. Um episódio semelhante ocorreu em 1624. Santagata, Istoria, 2: 330-31; Mazur, "Combating 'Mohammedan Indecency'," 37. Esta prática era comum em missões populares jesuítas: Gentilcore, “Adapt Yourselves", 281.

31 González, Manuductio, 2: 229.

$32 \mathrm{Na}$ Espanha, ver Relación de los maravillosos efectos que en la ciudad de Sevilla ha obrado una misión de los Padres de la Compañia de Jesús (Sevilla: sn, 1672). Em Nápoles, ver Archivio Pontificia Università Gregoriana 1060 I, 23; 61.

33 Em suas cartas, Loyola falou sobre o alto número de cristãos que "se converteram" durante suas missões junto aos muçulmanos (Archivio Pontificia Università Gregoriana $1060 \mathrm{I}, 10-11,24-25,64,221,228)$. 
34 González, Manuductio, 2:65. Ver argumentos semelhantes em Almarza, Catecismo, 1-15; Loyola, Archivio Pontificia Università Gregoriana 1060 I / 5.

35 González, Manuductio, 2: 40-44; Reyero (1913, p.289-93).

36 Archivum Romanum Societatis Ies, Neap. 204, 94.

37 González, Manuductio, 2: 295

38 Archivum Romanum Societatis Ies, Neap. 72 XIX, 138-140v.

39 Ver Almarza, Catecismo, 44-49 ("Impugnase la licencia de repudio"); González, Manuductio, 2:222-224.

40 Sobre Inácio, ver Colombo (2014). Na impressora, ver Castellani (1933, p.11-16); sobre o ensino do árabe, ver Villoslada (1954, p.71-2).

41 Em Spinelli, ver Barone (1707, p.100-1).

42 Ver também v.1, p.28, 95, 504-5, 572. Sobre as missões de Maniero em Argel, ver Archivum Romanum Societatis Ies, Ital. 171, 304-305v.

43 O manuscrito está preservado na Biblioteca Nazionale di Napoli, Ms. III F 52. Ver Bombaci (1940, p.205-36); Rocchi (2012); Santagata (1756-1757, v.2, p.99-102, 157, 348-58, 569-73). De acordo com Santagata, em 1617, um dicionário e uma gramática de árabe e mourisco foram publicados pela Congregação da Epifania como instrumentos para a conversão de escravos muçulmanos (ibidem, v.1, p.41-2).

44 González, Manuductio, 2: 303; Medina (1988, p.22).

45 O diálogo é transcrito em Bombaci (1940, p.230-6).

46 González, Manuductio, 2:155.

47 González, Manuductio, 2:296. A descrição da imponente cerimônia que precedeu os batismos de 38 muçulmanos em Sevilha, em 1672, circularam em um relatório impresso: Relación de los maravillosos efectos.

48 Os arcebispos de Nápoles batizaram os escravos muçulmanos que se converteram em missões jesuítas. Em 1605, o cardeal Ottavio Acquaviva batizou 21 escravos. Santagata (1756-1757, v.1, p.167-8). Em 1620, o cardeal Decio Carafa batizou vinte escravos e confirmou mais cem. Santagata (1756-1757, v.2, p.156-7). Em 1640, o cardeal Francesco III Boncompagni converteu e confirmou um grupo de escravos. Archivum Romanum Societatis Ies, Neap. 74, 14-15. Sobre a presença de autoridades civis nos batismos na Espanha, ver González, Manuductio, 2:295. Em Nápoles, ver Santagata (1756-1757, v.1, p.167-8; v.2, p.156-7).

49 Baldassarre Loyola, Archivio Pontificia Università Gregoriana, 1060 I, 20.

50 González, Manuductio, 2: 304.

51 O Oratório para os Escravos Batizados (Oratorio degli schiavi battezzati) foi fundado em 1605. Ver Archivum Romanum Societatis Ies, Neap. 72, XV-2, 8. A Casa dos Catecúmenos foi criada em 1637 pelo jesuíta Giovanni Battista Galeota e poderia hospedar por uma ou duas semanas muçulmanos que queriam converter. Durante os anos 1637 a 1649, a Casa dos Catecúmenos registrou cem batismos. Ver Boccadamo (2010, p.235, 239). Em 1659, os jesuítas pediram o apoio das autoridades civis para a construção de outra Casa dos Catecúmenos, o que sugere que o anterior já não existia. Ver Archivum Romanum Societatis Ies, Opp. NN 75, 231-32. O projeto provavelmente não teve sucesso visto que Baldassarre Loyola, que estava em Nápoles em 
1666, nunca mencionou o caso em suas várias cartas. Para a Casa dos Catecúmenos em Roma, ver Collenberg (1989).

52 González, Manuductio, 2:299.

53 Guillén para Oliva, Jesús del Monte, 10 de julho de 1670, em Reyero (1913, p.237).

54 Brunacci, Vita, 113; Baldassarre Loyola, Archivio Pontificia Università Gregoriana, 1060 I, 158-59.

55 Guillén para Gianpaolo Oliva, Jesús del Monte, 10 de julho de 1670, em Reyero (1913, p.236-46).

56 Em Pacheco, ver O’Neill e Domínguez, 2001, 3: 2941; Borja Medina (1988, p.11819).

57 Pacheco foi enviado para Lecce, onde Bernardino Realino foi ativo na conversão de escravos muçulmanos. Ver Archivum Romanum Societatis Ies, Vita 125 II, 448-462.

58 Brunacci, Vita, 75.

59 Gentilcore, “'Adapt Yourselves'," 272; Francesco Maria d'Aria (1943, p.619-32).

60 Poch para Oliva, 2 de julho de 1676 e 27 de março de 1680, Archivum Romanum Societatis Ies, Arag. 27 II, 86, 92.

61 A primeira aparição da expressão “outras Índias”, usada na Companhia de Jesus para descrever missões particularmente desafiadoras na Europa, encontra-se em uma carta de 1556 de Cristóbal Rodríguez, onde ele descreve a difícil conversão dos mouriscos. Ver Prosperi (1995, p.179; 1999, p.65-87).

\section{Referências}

ACERO, B. A. Sultanes de Berbería, nas tierras de la cristiandad: Exilio musulmán, conversión y asimilación en la monarquía hispánica (siglos XVI e XVII). Barcelona: Bellaterra, 2006.

BARONE, A. Della vita del Padre Pierantonio Spinelli della Compagnia di Giesì. Napoli: s. n. 1707. p.100-1.

BENNASSAR, B.; BENNASSAR, L. Les Chrétiens d'Allah: L'histoire extraordinaire des renégats, XVIe e XVIIe siècles. Paris: Perrins, 1989.

BOCCADAMO, G. Napoli e l'Islam: Storie di musulmani, schiavi e rinnegati in età moderna. Napoli: D’Auria, 2010.

BOMBACI, A. Padre Pietro Ferraguto e a sua Grammatica turca (1611). In: Annali dell'Istituto Orientale di Napoli, n.1, p.205-36, 1940.

BONIS, C. de. Vita del Padre Francesco di Geronimo della Compagnia de Gesù. Napoli: Muzio, 1747. p.29-30.

BONO, S. Schiavi musulmani nell'Italia moderna: Galeotti, vu'cumprà, domestici. Napoli: Edizioni Scientifiche Italiane, 1999.

La schiavitù nel mediterraneo moderno: Storia di una storia. Cabiers de la Méditerranée, v.65, p.1-16, 2002.

BROGGIO, P. Evangelizzare il mondo: Le missioni della Compagnia di Gesù tra Europa e America (secoli XVI-XVII). Roma: Carocci, 2004. p.51. 
CALLADO, F. L. R. Misiones populares em Espanha entre el Barroco y la Ilustración. Valencia: Alfons el Magnànim, 2006.

CASTELLANI, G. La tipografia del Collegio Romano. Archivum Historicum Societatis Iesu, v.3, p.11-16, 1993.

COLLENBERG, W. R. De. Le baptême des musulmans esclaves a Rome aux XVI e et XVIIe siècles. Mélanges de l'Ecole Française de Rome, v.101, p.9-181, 1989.

COLOMBO, E. Jesuits and Islam in Seventeenth-Century Europe: War, Preaching, and Conversion. In: HEYBERGER, B. et al. (Ed.) L'islam visto da Occidente. Cultura e religione del Seicento europeo di fronte all'Islam. Milano-Genova: Marietti, 2009. p.315-40.

. Even among Turks: Tirso González de Santalla (1624-1705) and Islam. Studies on Jesuit Spirituality, v.44, n.3, 2012a.

In virtù dell'obbedienza. Tirso González de Santalla (1624-1705) missionario, teologo, generale. In: FERLAN, C.; ALFIERI, F. (Ed.) Avventure dell'obbedienza nella Compagnia di Gesì. Teorie e prassi fra XVI e XIX secolo. Bologna: Il Mulino, 2012b. p.97-137.

. A Muslim Turned Jesuit: Baldassarre Loyola Mandes (1631-1667). Journal of Early Modern History, v.17, p.479-504, 2013.

Defeating the Infidels, Helping their Souls: Ignatius Loyola and Islam. In: MARYKS, R. (Ed.) Brill's Companion to Ignatius of Loyola: Life, Writings, Spirituality. Leiden: Brill, 2014.

D'ARIA, F. M. Un restauratore sociale: Storia critica della vita di San Francesco de Geronimo da documenti inediti. Roma: Edizioni Italiane, 1943. p.619-32.

DACKHLIA, J.; VINCENT, B. (Ed.) Les musulmans dans l'histoire de l'Europe. Paris: Albin Michel, 2011. v.1: Une intégration invisible.

Les musulmans dans l'histoire de l'Europe. Paris: Albin Michel, 2013. v.2: Passagens e contatos em Méditerranée.

DANIEL, N. Islam and the West: The Making of an Image. Edinburgh: Edinburgh University Press, 1960. p.175-84.

DIVENUTO, F. (Ed.) Napoli, L’Europa, e a Compagnia de Gesì nella "Cronica” de Giovan Francesco Araldo. Napoli: Edizioni Scientifiche Italiane, 1998.

DURSTELER, E. Renegade Women: Gender, Identity, and Boundaries in the Early Modern Mediterranean. Baltimore: Johns Hopkins University Press, 2011.

. Conversion in the Early Modern World. Special issue of the Journal of Early Modern History, v.17, 2013.

Space and Conversion: a Global Approach $\left(16^{\text {th }}-20^{\text {th }}\right.$ centuries $)$. Ed. Giuseppe Marcocci, Aliocha Maldavski, Ilaria Pavan, Wietse de Boer. Leiden: Brill, 2014.

FUMAROLI, M. Héros e orateurs: Rhétorique et dramaturgie cornéliennes. Genève: Droz, 1990.

GARCÍA-ARENAL, M.; MEDIANO, F. R. Historia del Colegio de San Pablo, Granada 1554-1765. In: BÉTHENCOURT, J. de (Ed.) Archivo Histórico Nacional, Madrid, Ms Jesuitas, Libro 773. Ed. Olivares. Granada: Facultad de Teología, 1991. p.413-14. 
GARCÍA-ARENAL, M.; MEDIANO, F. R.The Orient in Spain. Converted Muslims, the Forged Lead Books of Granada and the Rise of Orientalism. Leiden: Brill, 2013. p.315-19.

GENTILCORE, D. “Adapt Yourselves to the People's Capabilities”: Missionary Strategies, Methods and Impact in the Kingdom of Naples, 1600-1800. Journal of Ecclesiastic History, v.45, p.269-96, 1994.

GONZÁLEZ, Veritas religionis christianae demonstram adversus omnes infidels. Napoli: Muzio, 1702.

HEYBERGER, B. Polemic Dialogues between Christians and Muslims in the Seventeenth Century. Journal of the Economic and Social History of the Orient, v.55, p.495-516, 2012.

IBARRA, M. A. de B. La imagen de los musulmanes y del Norte de África en la España de los siglos XVI y XVII. Los caracteres de una hostilidad. Madrid: Consejo Superior de Investigaciones Científicas, 1989.

KEDAN, B. Z. Muslim Conversion in Canon Law. In: Proceedings of the Sixth International Congress of Medieval Canon Law, Berkeley, California, 28 July - 2 August 1980. Ed. Stephan Kuttner and Kenneth Pennington. Città del Vaticano: Biblioteca Apostolica Vaticana, 1985. p.321-32.

KRSTIC, T. Contested Conversions to Islam. Narratives of Religious Change in the Early Modern Ottoman Empire. Stanford: Stanford University Press, 2011.

LAZAR, L. G. Working in the Vineyard of the Lord: Jesuit Confraternities in Early Modern Italy. Toronto: University of Toronto Press, 2005.

LUCA, G. B. de. Il Dottor Volgare, ossia il compendio di tutta la legge civile, canonica, feudale e municipale. Roma: Corvo, 1673. v.4, p.18-19.

MAJORANA, B. Une pastorale spectaculaire: Missions et missionaires jésuites en Italie (XVIe-XVIIe siècle). Annales, v.57, p.297-332, 2002.

MAZUR, P. Combating 'Mohammedan Indecency': The Baptism of Muslim Slaves in Spanish Naples, 1563-1667. Journal of Early Modern History, v.13, p.25-48, 28, 2009.

A Mediterranean Port in the Confessional Age: Religious Minorities in Early Modern Naples. In: ASTARITA, T. (Ed.) A Companion to Early Modern Naples. Leiden: Brill, 2013. p.215-34, 224.

MEDINA, F. de B. La Compañía de Jesus y la minoría morisca (1545-1614). Archivum Historicum Societatis Iesu, v.57, p.3-136, 1988.

NARDI, G. Due opere per la conversione degli schiavi a Napoli, Asprenas, v.13, p.170$205,1966$.

Nuove ricerche sulle congregazioni napoletane a favore degli schiavi: La congregazione degli schiavi dei PP. Gesuiti. Asprenas, v.15, p.294-313, 1967.

O’NEILL, C. E.; DOMínguEZ, J. M. (Ed.) Diccionario histórico de la Compañía de Jesús: biográfico-temático. Roma; Madrid: Institutum Historicum Societatis Iesu-Universidad Pontificia Comillas, 2001.

PEREDA, F. Las imágenes de la discordia. Política y poética de la imagen sagrada en la España del cuatrocientos. Madrid: Marcial Pons, 2008. 
PIZZORUSSO, G. La preparazione linguistica e controversistica dei missionari per l'Oriente islamico: scuole, testi, insegnanti a Roma e in Italia. In: HEYBERGER, B. et al. (Ed.) L'islam visto da occidente. Cultura e religione del Seicento europeo di fronte all'Islam. Milano-Genova: Marietti, 2009. p.253-88.

POUMAREDE, G. Pour en finir avec la Croisade: mythes et réalités de la lutte contre les Turcs aux XVIe et XVIIe siècles. Paris: Presses Universitaires de France, 2009.

POUTRIN, I. Convertir les musulmans: Espagne, 1491-1609. Paris: Presses Universitaires de France, 2012.

PROSPERI, A. The Missionary. In: VILLARI, R. (Ed.) Baroque Personae. Chicago: The University of Chicago Press, 1995. p.160-94.

Otras Indias. Missionari della Controriforma tra contadini e selvaggi. In:

America e apocalisse e altri saggi. Roma-Pisa: Istituti Editoriali e Poligrafici Internazionali, 1999. p.65-87.

REYERO, E. Misiones del Padre Tirso González de Santalla, XIII prepósito general da Compañia de Jesús. Santiago de Compostela: Editorial Compostelana, 1913.

ROCCHI, L. Il "Dittionario della lingua turchesca" di Pietro Ferraguto (1611). Trieste: Edizioni Università di Trieste, 2012.

ROSCIONI, G. Il desiderio delle Indie: Storie, sogni e fughe di giovani gesuiti italiani. Torino: Einaudi, 2000.

SANTAGATA, S. Istoria della Compagnia di Gesì appartenente al Regno di Napoli. Napoli: Mazzola, 1756-1757. 2v., v.1, p.28-30.

SANTALLA, T. G. de. Manuductio ad converem Mahumetanorum en duas partes divisa. Madrid: Villa-Diego, 1687. 2v.

SCHINOSI, F. Istoria della Compagnia di Gesì, appartenente al Regno di Napoli. Napoli: Mutio: 1706-1711. v.1, p.431-2.

SELWYN, J. D. A Paradise Inhabited by Devils: The Jesuits' Civilizing Mission in Early Modern Naples. Burlinton-Rome: Ashgate-IHSI, 2004.

STELLA, A. Histoires d'esclaves dans la péninsule Ibérique. Paris: EHESS, 2000.

TEJADA, F. E. de. Nápoles Hispánico. Madrid: Montejurra, 1959. v.3: Las Españas Aureas 1554-1598, p.147-64.

VALENSI, L. Ces étrangers familiers. Musulmans en Europe (xvie-xviiie siècles). Paris: Payot, 2012.

VILLOSLADA, R. G. Storia del Collegio romano dal suo inizio (1551) alla soppressione della Compagnia di Gesù (1773). Roma: Università Gregoriana, 1954. p.71-2.

VINCENT, B. Les musulmans dans l'Espagne moderne. Les Musulmans dans l'Histoire d'Europe, v.1, p.615, s. d.

Musulmans et conversion en Espagne au XVII ${ }^{\mathrm{e}}$ siècle. In: GARCIA-ARENAL, M. (Ed.) Conversions islamiques: identités religieuses en Islam méditerranéen. Paris: Maisonneuve et Larose, 2001. p.193-203. 
RESUMO - A partir de fontes jesuítas publicadas e não publicadas - tratados, manuais, relatórios e cartas -, este artigo explora o apostolado jesuíta referente aos escravos muçulmanos em Nápoles e em diferentes cidades da Espanha durante o século XVII. Um ponto de vista jesuíta, encoberto pela retórica missionária e indisponível de outra forma, é encontrado nestas fontes, as quais destacam os métodos e estratégias missionárias jesuíticas além de esclarecerem o status especial do apostolado para os escravos muçulmanos na mente jesuíta. Enquanto a Europa estava enviando missionários para converter os escravos muçulmanos (e as missões foram consideradas uma variação das então chamadas "missões populares") a essas missões muitas vezes era atribuído um valor simbólico mais profundo. Uma vez que os interlocutores dos missionários eram "infiéis", tão diferentes tanto em sua cultura quanto em seus hábitos, os jesuítas usavam formas de acomodação extremamente semelhantes às que eram usadas nas missões no ultramar. A conversão de escravos muçulmanos em Nápoles ou na Espanha foi concebida pelos jesuítas como um caminho alternativo e eficaz para realizar uma missão "mesmo em meio aos Turcos", como afirmava a Fórmula do Instituto, apesar de nunca ter deixado os reinos europeus para terras otomanas. Situada entre as missões no ultramar, onde os jesuítas convertiam os "infiéis" em terras distantes, e as missões na Europa, onde eles tentavam salvar as almas de pessoas batizadas que não tinham educação religiosa, havia “outras Índias", onde os jesuítas podiam encontrar, converter e batizar os "infiéis" em casa.

PALAVRAS-CHAVE: Jesuítas, Muçulmanos, Escravos, Alojamento, “Outras Índias”, Missões populares, Conversão, Baldassare Loyola, Nápoles, Espanha.

ABSTRACT - Drawing from published and unpublished Jesuit sources - treatises, handbooks, reports, and letters - this article explores the Jesuit apostolate to Muslim slaves in Naples and in different cities of Spain during the seventeenth century. Under the blanket of missionary rhetoric, a Jesuit viewpoint not otherwise available is found in these sources, which highlight their missionary methods and strategies and clarify the special status of the apostolate to Muslim slaves in the Jesuit mind. While Europe was the setting of missions to Muslim slaves and the missions were considered a variation of the so-called popular missions, they were often charged with a deeper symbolic value. Because the missionaries' interlocutors were "infidels," so different in their culture and in their habits, Jesuits used forms of accommodation extremely similar to those they used in the missions overseas. Converting Muslim slaves in Naples or in Spain was conceived by Jesuits as an alternative and effective way to go on a mission "even among Turks," as the Jesuit Formula of the Institute stated, despite never leaving European kingdoms for Ottoman lands. Located between the missions overseas, where Jesuits converted the "infidels" in distant lands, and the missions in Europe, where they attempted to save the souls of baptized people who lacked religious education, were "other Indies," where Jesuits could encounter, convert, and baptize the "infidels" at home.

KErWORDs: Jesuit, Muslims, Slaves, Accommodation, “Other Indies”, Popular missions, Conversion, Baldassare Loyola, Naples, Spain.

Emanuele Colombo é professora associada do Departamento de Estudos Católicos da Chicago DePaul University. Doutora em História da Igreja pela Universidade de Milão e Pádua, Itália. @ - ecolombo@depaul.edu / https://orcid.org/0000-0001-5787-3871

${ }^{\mathrm{I}}$ Departamento de Estudos Católicos, Chicago DePaul University, Chicago, USA.

Recebido em 3.7.2019 e aceito em 11.8.2019. 
